\title{
Interaction of Dioxovanadium (V) ion with L-alanine at Different lonic Strengths
}

\author{
M. H. Fekri ${ }^{*}$, F. Gharib ${ }^{2}$, M. Darvishpour ${ }^{3}$ \\ ${ }^{1}$ Department of Chemistry, Ayatollah Alozma Boroujerdi University, Boroujerd, Iran. \\ m.h.fekri@abru.ac.ir \\ ${ }^{2}$ Chemistry Department,Faculty of Sciences,Shahid Beheshti University,Tehran,Evin, Iran. \\ f-gharib@cc.sbu.ac.ir \\ ${ }^{3}$ Department of Chemistry, Razi University, Kermanshah, Iran. \\ maryam_59d@yahoo.com
}

\section{ABSTRACT}

The formation constants of species formed in the system $\mathrm{H}^{+}+$alanine and $\mathrm{VO}_{2}{ }^{+}+$alanine have been determined in aqueous solution for $1.0<\mathrm{pH}<7.0$ and at different ionic strengths ranging from 0.1 to $1.0 \mathrm{~mol} \mathrm{dm}^{-3} \mathrm{NaClO}_{4}$, using a combination of potentiometric and spectrophotometric techniques. The compositions of the formd complexes and their stability constants were determined by curve fitting method and it was shown that dioxivanadium(V) forms two mononuclear $1: 1$ and 1:2 species with alanineof type $\mathrm{VO}_{2} \mathrm{~L}$ and $\mathrm{VO}_{2} \mathrm{~L}_{2}$. The porotonation constant of the amino group of alanine has been determined using potentiometric techniques and calculated using a computer program wich employ a least-squares method. The dependence of the porotonation of alanine and the stability constants of the species on ionic strength are described by a deby-huckel type equation.

\section{Keywords}

Stability constants; Dioxivanadium(V); Alanine; lonic strength; Fitting method.

\section{Council for Innovative Research}

Peer Review Research Publishing System

\section{Journal: Journal of Advances in Chemistry}

\author{
Vol. 5, No. 1 \\ editor@cirworld.com \\ www.cirworld.com, member.cirworld.com
}




\section{INTRODUCTION}

Interactuon between amino acids, peptides and proteins with transition metal ions plays an important role in biochemistry and biology.Great attention has been paid to elucidating and interpreting the thermodynamic and structural characteristics of these biological ligands complexes. Vanadium complexes are particularly susceptible to external influences since the vanadium atom is small and readily accommodates several coordination geometries[1]. The recent human clinical trials using vanadium compounds as oral insulin substitutes are encouraging[2-5], but the mechanism and the site of action are not yet known. It has been suggested that vanadate will spontaneously vanadylate a tyrosine residue in the insulin receptor, leading to titrations. We have reported some interesting features of the function $\log \beta=f(I)$, where $\beta$ and $I$ refer to the stability constant and ionic strength, respectively [6-9]. In particular, all formation constants seem to follow the same trend as a function of ionic strength, if allowance is made for different types of reaction stoichiometry and different charges of reactants and products. In determining a formation constant at a fixed ionic strength, in all cases, some uncertainties are present. For example, the 0.9 log unit difference in the stability constants determined at 0.1 and $0.7 \mathrm{~mol} \mathrm{dm}^{-3} \mathrm{should}$ be the result of the uncertainties in the numerical values. The present work deals with the study of dioxovanadium $(\mathrm{V})$ ion, $\mathrm{VO}_{2}{ }^{+}$, with L-alanine in aqueous solution at $25^{\circ} \mathrm{C}$ and different ionic strength, 0.1 to $1.0 \mathrm{~mol} \mathrm{dm}$, of sodium perchlorate, using a combination of potentiometric and spectrophotometric techniques. The parameters which define this dependency were analyzed with the aim of obtaining further information with regard to their variation as a function of charges involved in the complex formation reaction. Moreover, a Debye-Hückel type equation was established for the dependence of formation constant on ionic strength. This equation gives the possibility of estimating a formation constant at a fixed ionic strength when its value is known at another ionic strength in the range $0.1<1<1.0 \mathrm{~mol} \mathrm{dm}^{-3}$, and therefore may give a significant contribution of solving many analytical and speciation problems.

\section{Results and Discussion}

\subsection{The chemistry}

The complex $\mathrm{M}_{\mathrm{p}} \mathrm{H}_{\mathrm{q}} \mathrm{L}_{r}{ }^{(p+q-r)}$ formed, is characterized by its stoichiometry (p:q:r), where $M$ and $L$ represent the metal ion and the ligand, respectively. To determine the stability constant of complexation or protonation Eq. (2) is defined by $\beta_{\text {pqr. }}$

$$
\begin{aligned}
& \mathrm{pM}^{+}+\mathrm{qH}^{+}+\mathrm{rL}^{-} \leftrightarrow \mathrm{M}_{\mathrm{p}} \mathrm{H}_{\mathrm{q}} \mathrm{L}_{r}{ }^{(\mathrm{p}+\mathrm{q}-\mathrm{r})} \\
& \beta_{\mathrm{pqr}}=\left[\mathrm{M}_{\mathrm{p}} \mathrm{H}_{\mathrm{q}} \mathrm{L}_{r}^{(\mathrm{p}+\mathrm{q}-\mathrm{r})}\right] /\left(\left[\mathrm{M}^{+}\right]^{\mathrm{p}}\left[\mathrm{H}^{+}\right]^{\mathrm{q}}\left[\mathrm{L}^{-}\right]^{r}\right.
\end{aligned}
$$

The protonation constant of alanine has been used for computation of the stability constant, $\beta_{\text {pqr }}$, of the metal-ligand.The protonation constants of the ligand have been extensively studied in different kind of background electrolytes and the results were reported in literature. In this work, the protonation constants of alanine were determined at different ionic strengths of sodium perchlorate using potentiometric technique and calculated using a computer program which employs a nonlinear least-squares method [14].These values are listed in Table 1. The method of determination of the stability constant was based on the relation $A=f\left[\mathrm{H}^{+}\right]$[10]. Absorbance, $A$, and -log $\left[\mathrm{H}^{+}\right]$were measured as described before.Treatments of the spectrophotometric data (each $5 \mathrm{~nm}$ ) obtained during the titration as a function of the hydrogen ion concentration were conducted to the computer program. The program allows calculation of the stability constant for different stoichiometry models. Considering the protonation constants of the ligand, in acidic solution the predominant species for complexation is $\mathrm{HL}$. In this case the spectrophotometric titration data were analyzed by using the absorbance of $\mathrm{VO}_{2}^{+}$+alanine at a wavelength in the UV range that is given by,

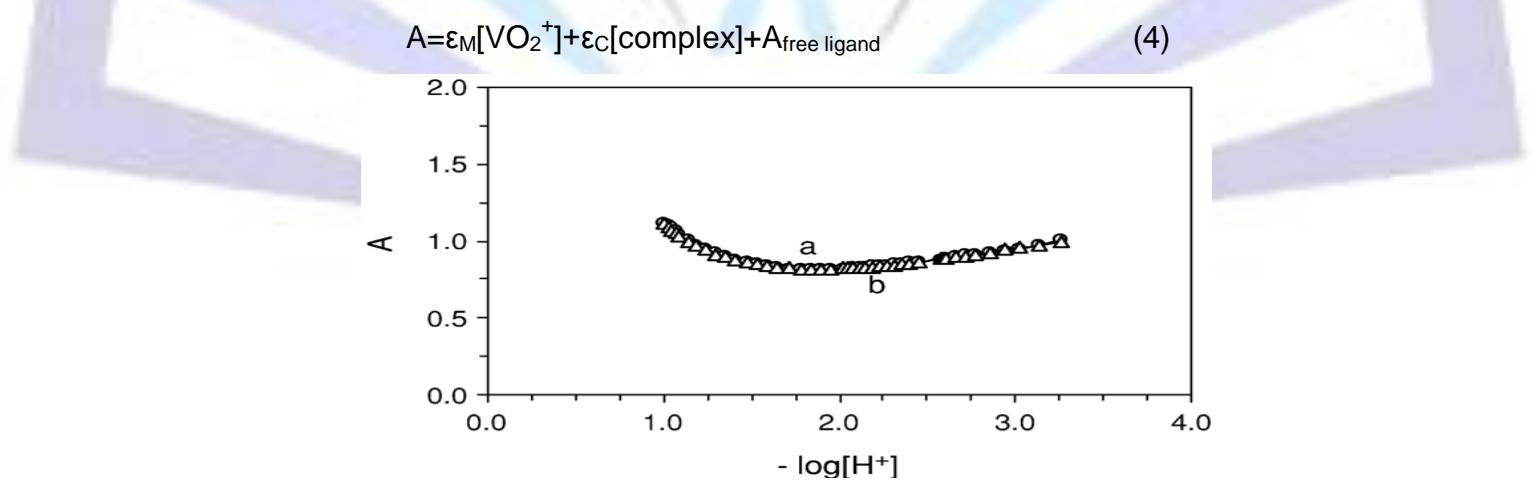

Fig. 1. A typical graphical fitting for $\mathrm{VO}_{2}{ }^{+}$+alanine system at $25^{\circ} \mathrm{C}, 265 \mathrm{~nm}$,and ionic strength $0.1 \mathrm{~mol} \mathrm{dm}^{-3}$ $\mathrm{NaClO}_{4}$, (a) experimental absorbance (•),(b) calculated absorbance from the computer program by the fitting $\operatorname{method}(\Delta)$.

where $\varepsilon_{\mathrm{M}}$ and $\varepsilon_{\mathrm{C}}$ are the molar absorbance coefficients of $\mathrm{VO}_{2}{ }^{+}$and the complex species, respectively. For the mass balance,

$$
\begin{aligned}
& {\left[\mathrm{VO}_{2}{ }^{+}\right]=\mathrm{C}_{\mathrm{M}}-[\text { complex }]} \\
& {[\mathrm{HL}]=\mathrm{C}_{\mathrm{L}}-[\text { complex]-[free ligand] }}
\end{aligned}
$$


Substituting Eqs. (3), (5) and (6) into Eq. (4) gives the final equation for fitting, where $C_{M}$ and $C_{L}$ are the total concentration of $\mathrm{VO}_{2}{ }^{+}$and the ligand, respectively. Using a suitable computer program [14] the data were fitted to the final equation for estimating the formation constant of Eq. (2).We used the Gauss-Newton nonlinear least-squares method in the computer program to refine the absorbance by minimizing the error squares sum from Eq. (7).

$$
\mathrm{S}=\Sigma\left(\mathrm{A}_{\mathrm{exp}}-\mathrm{A}_{\mathrm{cal}}\right)^{2}
$$

Where $A_{\text {exp }}$ is the observed absorbance and $A_{c a l}$ is a calculated one.The computer program permits two different kinds of fitting, (a) graphical, (b) numerical. The final selection of the species was based on both graphical and numerical methods,considering in addition the various statistical criteria, i. e. sum those of calculated ones. Fig. 1 is shown as a typical example of a graphical fitting for the observed and calculated absorbances (from the computer program) of $\mathrm{VO}_{2}{ }^{+}+$ serine system against $-\log \left[\mathrm{H}^{+}\right]$.Different models of complexation including $\mathrm{MHL}_{2}{ }^{+}, \mathrm{M}(\mathrm{HL})_{2}{ }^{2+}$ and several polynuclear and protonated species were tested by the program. As expected, polynuclear complexes were systematically rejected by the computer program, as also were $\mathrm{VO}_{2} \mathrm{~L}$ and $\mathrm{VO}_{2} \mathrm{~L}_{2}$. The average values for various wavelengths calculated for the stability constants are listed in Table 2.

Table 2. Average values of $\log \beta_{111}$ and $\log \beta_{122}$ of the system $\mathrm{VO}_{2}{ }^{+}+$alanine for various wavelengths $(260-275 \mathrm{~nm})$ at $25^{\circ} \mathrm{C}$ and different ionic strengthsb of sodium perchlorate.

\begin{tabular}{|c|c|c|}
\hline $\mathrm{I} / \mathrm{mol} \mathrm{dm}^{-3}$ & $\log \beta_{111}$ & $\log \beta_{122}$ \\
\hline 0.1 & $10.57 \pm 0.06$ & $19.55 \pm 0.05$ \\
\hline 0.3 & $10.26 \pm 0.07$ & $19.44 \pm 0.08$ \\
\hline 0.5 & $10.36 \pm 0.07$ & $19.48 \pm 0.07$ \\
\hline 0.7 & $10.59 \pm 0.06$ & $19.66 \pm 0.05$ \\
\hline 1.0 & $10.92 \pm 0.05$ & $20.64 \pm 0.06$ \\
\hline
\end{tabular}

In Fig. $2 \mathrm{a}$ and $2 \mathrm{~b}$ the equilibrium distribution of various species in the $\mathrm{VO}_{2}{ }^{+}+$alanine system is shown as a function of $-\log \left[\mathrm{H}^{+}\right]$.The calculation is based on the stability constant values given before. It is shown that the main species are $\mathrm{VO}_{2} \mathrm{~L}$ and $\mathrm{VO}_{2} \mathrm{~L}_{2}^{-}$.

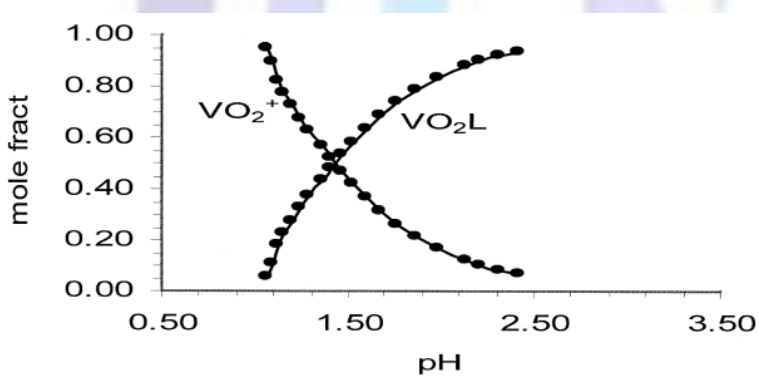

(a)

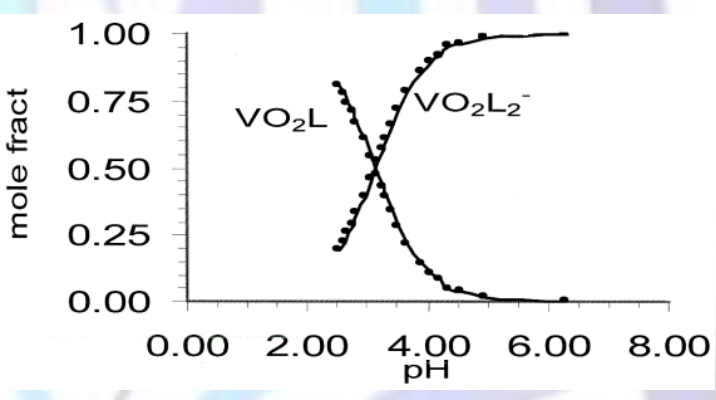

(b)

Fig. 2. The equilibrium distribution of the species in the $\mathrm{VO}_{2}{ }^{+}+$alanine system as a function of $-\log \left[\mathrm{H}^{+}\right]$at $25{ }^{\circ} \mathrm{C}$ and ionic strength $0.1 \mathrm{~mol} \mathrm{dm}^{-3} \mathrm{NaClO}_{4}$.

\section{2. lonic strength dependence}

The dependence of the stability constants on ionic strength for the complex species can be described by a semi-empirical equation $[6-9,15,16]$.

$$
\log \beta(I)=\log \beta\left(I^{*}\right)-A Z^{*}\left[I^{0.5} /\left(1+B I^{0.5}\right)-I^{* 0.5} /\left(1+B I^{* 0.5}\right)\right]+C\left(I-I^{*}\right)+D\left(I^{1.5}-I^{* 1.5}\right)+E\left(I^{2}-I^{* 2}\right)
$$

Where $I$ and $I^{*}$ are the actual and reference ionic strength,respectively. According to Eq. (8) $Z^{*}=\Sigma(\text { charges })^{2}$ reactants $-\Sigma$ (charges) ${ }^{2}$ products. Considering $A=0.5115+8.885 \times 10^{-4}(t-25)+2.953 \times 10^{-6} \quad(t-25)^{2}$ and $\mathrm{B}=1.489+8.772 \times 10^{-4}(\mathrm{t}-25)+4.693 \times 10^{-6}(\mathrm{t}-25)^{2}[15]$, where $\mathrm{t}$ is the temperature in degrees Celsius, Eq. (8) can simplified at $\mathrm{t}=25^{\circ} \mathrm{C}$ to,

$$
\log \beta(I)=\log \beta\left(I^{*}\right)-Z^{*}\left[I^{0.5} /\left(2+3 I^{0.5}\right)-I^{* 0.5} /\left(2+3 I^{* 0.5}\right)\right]+C\left(I-I^{*}\right)+D\left(I^{1.5}-I^{* 1.5}\right)+E\left(I^{2}-I^{* 2}\right)
$$

Where C,D an are empirical coefficients whose values are considered. The validity of Eq. (9) has been discussed $E$ in previous papers mainly with speciation problems [6-9] where the possibility of calculating $\log \beta$ values, at the desired ionic strength using literature values, is of great importance. The parameters $C$ and $D$ were determined by a regression method with a suitable computer program [14]. The dependence of $\log \beta$ on ionic strength determined in $\mathrm{NaClO} 4$ as background electrolyte, Fig. 3, shows a regular trend and is in good agreement with other complex species [6-9,15-18]. Our previous results on ionic strength dependence of complex formation constants [6-9] and this work reveal the $\log \beta$ values are nearly 
always at their minimum at an ionic strength range $(0.3-0.7) \mathrm{mol} \mathrm{dm}^{-3}$, that is a characteristic of the curve log $\beta=f(I)$. According to the theory of electrolytic solutions [16] the $\mathrm{Al}^{1 / 2}$ term in Eq. (9) accounts for Coulomb interactions between ions screened by the ion atmosphere, while the $\mathrm{BI}$ term accounts for disturbances in ion-solvent interaction. At low ionic strength (less than about $0.1 \mathrm{~mol} \mathrm{dm}^{-3}$ ) these interactions are of primary importance. However, as the ionic strength increases, the ionic atmosphere becomes more compressed and screens the ionic charges more effectively, so that intermolecular interactions (dipole-dipole or multipole-multipole) become more important. These forces at higher ionic strength possibly play a primary role between the ions and contribute to the C,D and E terms in Eq. (9).
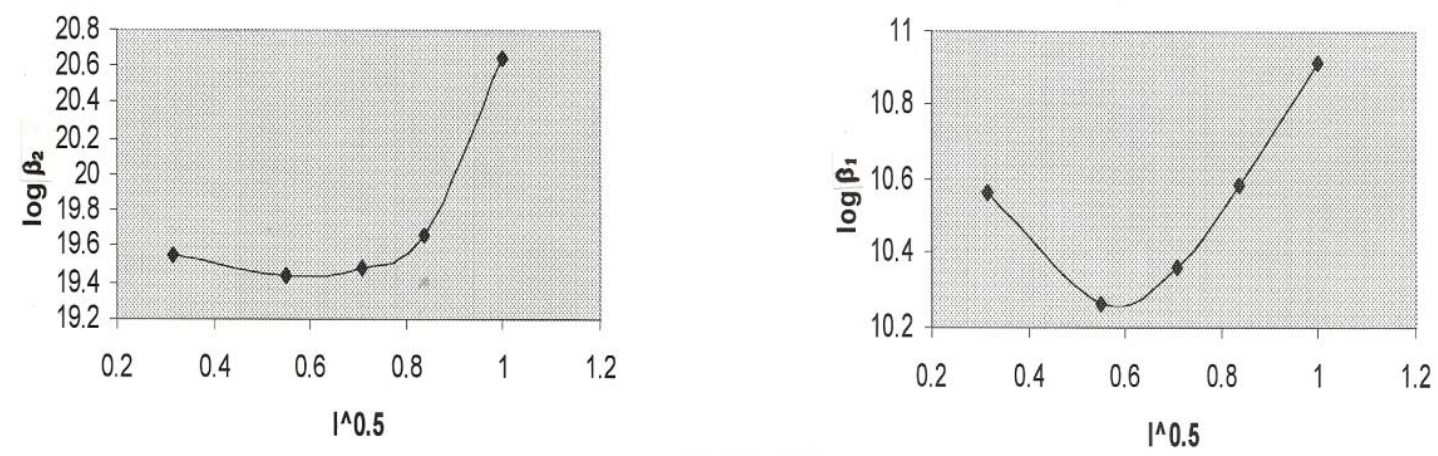

Fig. 3. Plots of $\log \beta$ versus square root of ionic strength (in molar scale) for $\mathrm{VO}_{2}{ }^{+}+$alanine at $25^{\circ} \mathrm{C}$.

\section{Experimental}

\subsection{Chemicals}

L-alanine (Fluka, analytical reagent grade) was recrystallized from hot water, washed with ethanol, and dried over $\mathrm{P}_{2} \mathrm{O}_{5}$ ,and its concentration was determined by titration against standard alkali. The $\mathrm{NaOH}$ solution was prepared from titrisol solution (E.Merck) and its concentration was determined by several titrations with standard HCl. Perchloric acid, sodium perchlorate and sodium monovanadate were supplied from E. Merck as analytical reagent grade materials and were used without further purification. Dilute perchloric acid solution was standardized against standard $\mathrm{NaOH}$ solution. All dilute solutions were prepared from double-distilled water with specific conductance equal to $(1.3 \pm 0.1) \times 10^{-4} \Omega^{-1} \mathrm{~m}^{-1}$. A stock solution of vanadium( $\mathrm{V})$ was prepared by dissolution of sodium monovanadate in perchloric acid solution effecting destruction of decavanadate. To avoid isopolyvanadate formation, the solution was allowed to stand overnight before use to obtain only the $\mathrm{VO}_{2}{ }^{+}$ion. Under this condition, both polymerization and hydrolysis of $\mathrm{VO}_{2}{ }^{+}$were negligible [10,11] The concentration of the vanadium ion in the stock solution was checked by potentiometric titration using saturated calomel and platinum wire electrodes. Titrations were performed on aliquots, after dilution in $\mathrm{H}_{2} \mathrm{SO}_{4}$ solution [12].

\subsection{Apparatus}

An Eyela pH-meter, PHM 2000, was used for - $\log \left[\mathrm{H}^{+}\right]$measurements. A purified nitrogen atmosphere was maintained in the reaction vessel during the titrations. The hydrogen ion concentration was measured with an Ingold UO 3234 glass electrode and an Ingold UO 3236 calomel electrode. Spectrophotometric measurements were performed on a UV-Vis Shimadzu 2100 spectrophotometer with a GDU-20 computer using thermostated matched $10 \mathrm{~mm}$ quartz cells. The measurement cell was of flow type. A Masterflex pump allowed circulation of the solution under study from the potentiometric cell to the spectrophotometric cell, so the absorbance and $-\log \left[\mathrm{H}^{+}\right]$of the solution could be measured simultaneously.

\subsection{Measurements}

All measurementswere carried out at $25 \pm 0.1{ }^{\circ} \mathrm{C}$. The ionic strength was maintained to $0.1-1.0 \mathrm{~mol} \mathrm{dm}^{-3}$ with sodium perchlorate. The $\mathrm{pH}$-meter was calibrated for the relevant $\mathrm{H}^{+}$concentration with a solution of $0.01 \mathrm{~mol} \mathrm{dm}^{-3}$ perchloric acid solution containing $0.09 \mathrm{~mol} \mathrm{dm}^{-3}$ sodium perchlorate (for adjusting the ionic strength to $0.1 \mathrm{~mol} \mathrm{dm}^{-3}$ ). The same procedure was performed for the other ionic strengths. For these standard solutions, we set $-\log \left[\mathrm{H}^{+}\right]=2.00[13]$. Junction potential corrections have been calculated from Eq. (1).

$$
-\log \left[\mathrm{H}^{+}\right]_{\text {real }}=-\log \left[\mathrm{H}^{+}\right]_{\text {measured }}+\mathrm{a}+\mathrm{b}\left[\mathrm{H}^{+}\right]_{\text {measured }}
$$

where $\mathrm{a}$ and $\mathrm{b}$ were determined by the measuring of hydrogen ion concentration for two different solutions of $\mathrm{HClO}_{4}$ with sufficient $\mathrm{NaClO}_{4}$ to adjust the ionic media.

\subsection{Procedure}

A $50 \mathrm{~cm}^{3}$ acidic solution of $\mathrm{VO}_{2}^{+}$was titrated with an alkali solution $\left(0.1 \mathrm{~mol} \mathrm{dm}{ }^{-3} \mathrm{NaOH}\right)$ of the ligand, both of the same ionic strength. The $-\log \left[\mathrm{H}^{+}\right]$and absorbance were measured after addition of a few drops of titrant, and this procedure was extended up to the required $-\log \left[\mathrm{H}^{+}\right]$. In all cases, the procedure was repeated at least three times and the resulting average values and corresponding deviations from the average are shown in the text and tables. 
Table 1.Protonation constants of $\mathrm{L}-$ alanine at $25^{\circ} \mathrm{C}$ and different ionic strengths of sodium perchlorate.

\begin{tabular}{|c|c|c|}
\hline $\mathrm{I} / \mathrm{mol} \mathrm{dm}^{-3}$ & $\log \beta_{011}$ & $\log \beta_{012}$ \\
\hline 0.1 & $0.80 \pm 0.06$ & $-0.78 \pm 0.04$ \\
\hline 0.3 & $0.56 \pm 0.05$ & $-0.52 \pm 0.03$ \\
\hline 0.5 & $0.86 \pm 0.05$ & $-0.38 \pm 0.04$ \\
\hline 0.7 & $0.98 \pm 0.07$ & $-0.54 \pm 0.02$ \\
\hline 1.0 & $1.18 \pm 0.04$ & $-0.02 \pm 0.03$ \\
\hline
\end{tabular}

\section{ACKNOWLEDGMENTS}

The authors express their appreciation to post-graduate office of Ayatollah Alozma Boroujerdi University for financial support of this work.

\section{REFERENCES}

[1]. D.C. Crans; A.D. Keramidas; M. Mahroof-Tahir; O.P. Anderson; M.M. Miller; 1996. Inorg. Chem., 35, 3599.

[2]. B.I. Posner; R. Faure; J.W. Burgess; A.P. Bevan; D. Lachance; G. Zhang Sun; I.G. Fantus; J.B. Ng; D.A. Hall; B. Soo Lum;1994. J. Biol. Chem. 269 , 4596.

[3]. J.H. McNeill; V.G. Yuen; H.R. Hoveyda; C. Orvig; 1992.J. Med. Chem., 35, 1489.

[4]. D.C. Crans; M. Mahroof-Tahir; O.P. Anderson; M.M. Miller; 1994. Inorg. Chem., 33 , 5586.

[5]. D.C. Crans; H. Holst; A.D. Keramidas; D. Rehder;1995. Inorg. Chem., 34 , 2524.

[6]. F. Gharib; L.A. Dogaheh; 2003. J. Chem. Eng. Data 48, 999.

[7]. F. Gharib; K. Zare; A. Taghvamanesh; A. Shamel; 2002. Main Group Met. Chem. 25, 647.

[8]. F. Gharib; F.S. Nik; 2004. J. Chem. Eng. Data 49 , 271.

[9]. F. Gharib; K. Zare; R. Cheraghali; Russ.2004. J. Inorg. Chem. 49 , 949.

[10]. J. Itoh; T. Yotsuyanagi; K. Amoura; 1975. Anal. Chim. Acta, $76,471$.

[11]. S. Yamada; J. Nagase; S. Funahashi; M. Tanaka; 1976. J. Inorg. Nucl. Chem., 38 , 617.

[12]. H.R. Grady; 1963. Analytical Chemistry of the Elements, Wiley Interscience, New York.

[13]. P. Lagrange, M. Schneider, K. Zare, J. Lagrange, 1994. Polyhedron 13 , 861.

[14]. D.C. Harris; 1998. J. Chem. Educ. 75, 119.

[15] P.G. Daniele; C. Rigano; S. Sammartano; 1983. Talanta 30 , 81.

[16] P.G. Daniele; C. Rigano; S. Sammartano; 1985. Anal. Chem. $57,2956$.

[17]. C.D. Stefano, C. Foti, A. Gianguzza, 1994. J. Chem. Res. 64.

[18]. C.D. Stefano, C. Foti, A. Gianguzza, M. Martino, L. Pellerito, S.Sammartano, 1996. J. Chem. Eng. Data 41, 511.

[19] R.S. Berry, S.A. Rice, J. Ross, 1980. Physical Chemistry, John Wiley and Sons,New York. 